\title{
PENGARUH KUALITAS LAYANAN, HARGA, PROMOSI TERHADAP KEPUASAN WISATAWAN DAN MINAT KUNJUNGAN KEMBALI (Studi pada Pengunjung Objek Wisata Air Owabong Kabupaten Purbalingga)
}

\author{
Ari Ardi Susanto \\ Universitas Muhammadiyah Purwokerto \\ Tri Septin Muji Rahayu \\ Universitas Muhammadiyah Purwokerto
}

\begin{abstract}
ABSTRAK
The study aims to determine the effect of service quality, price, promotion variables to tourist satisfaction and interests to revisit. The researcher collected the samples by distributing questionnaires to respondents thought survey method. The sampling technique applied wa purposive sampling. The total samples were 96 respondents. IBM SPSS Statistics 21 applied to analyze the data. The analysis tools applied were validity test, reliability tast, classic assumption test, multiple linear regression analysis and simple linear regression. The partial test ( $t$ test) proves that the quality of service, price and promotion significanty affected the tourist satisfaction and tourist satisfaction significantly affected the interest to come back. The simultaneous test $(f$ test) indicated that the service quality, price and promotion significantly affected tourist satisfaction.
\end{abstract}

Keywords : service quality, price, promotion, tourist satisfaction, interest to come back.

\section{ABSTRAK}

Penelitian ini bertujuan untuk mengetahui pengaruh variabel kualitas layanan, harga, promosi terhadap kepuasan wisatawan dan minat kunjungan kembali. Dalam penelitian ini peneliti melakukan pengambilan sampel dengan membagikan kuesioner kepada responden, dengan menggunakan metode survey. Teknik pengambilan sampel yang digunakan dalam penelitian ini adalah purposive sampling. Jumlah sampel sebanyak 96 responden. Analisis ini menggunakan IBM SPSS Statistics 21. Alat analisis yang digunakan adalah uji validitas, uji reliabilitas, uji asumsi klasik, analisis regresi linier berganda dan regresi linier sederhana. Hasil penelitian dengan menggunakan uji parsial (uji t) membuktikan bahwa kualitas layanan, harga, promosi berpengaruh secara signifikan terhadap kepuasan wisatawan dan kepuasan wisatawan berpengaruh secara signifikan terhadap minat kunjungan kembali. Hasil penelitian menggunakan uji simultan (uji t) secara bersama-sama menunjukkan bahwa kualitas layanan, harga, promosi berpengaruh secara signifikan terhadap kepuasan wisatawan.

Kata Kunci :kualitas layanan, harga, promosi, kepuasan wisatawan, minat kunjungan kembali

\section{Pendahuluan}

Indonesia memiliki potensi wisata yang cukup besar baik wisata domestik maupun mancanegara, potensi wisata yang dapat dikembangkan juga sangat beragam baik wisata bahari, wisata spiritual, wisata alam, wisata air, dan lain - lain.Sektor pariwisata daerah diharapkan dapat membantu dalam menunjang pendapatan daerah, yang nantinya bisa digunakan untuk mengembangkan potensi daerah yang lain dan dapat meningkatkan pembangunan daerah yang lebih baik. Hal tersebut juga dapat diterapkan pada kabupaten Purbalingga untuk meningkatkan pendapatan daerahnya menurut data dari Tabloid Pamor yang di terbitkan pada tanggal 8 Januari 2016, menyatakan bahwa kunjungan wisatawan selama tahun 2015 di Kabupaten Purbalingga 
mencapai 1.579 .098 orang. Kunjungan terbanyak dari wisatawan nusantara sementara wisatawan mancanegara tercatat hanya mencapai 203 orang. Jika dibanding tahun 2014, jumlah wisatawan yang berkunjung mengalami peningkatan lebih dari 200 ribu orang (www.tabloidpamor.com).

Selama tahun 2015 jumlah kunjungan wisata terbanyak di daearah Purbalingga masih dipegang oleh Owabong Water Park yang mencapai lebih dari 800 ribu wisatawan, kemudian Sanggaluri Park 229.695, Goa Lawa 52.050 orang, Taman Wisata Pendidikan Purbasari Pancuranmas 114.598, Kolam renang Tirto Asri Walik 89.968, Buper Munjuluhur 34.756 orang, wana wisata Serang 6.196, Monumen Tempat Lahir Jenderal Soedirman 10.191, Pendakian Gunung Slamet 6.971 orang, Agro wisata Lembah Asri Serang (Desa Wisata Serang) 221.480, Desa wisata Panusupan termasuk didalamnya Petilasan Ardi Lawet mencapai 14.063 wisatawan (www.tabloidpamor.com) .

Untuk meningkatkan jumlah wisatawan harus memperhatikan unsur - unsur yang dapat memuaskan konsumen sehingga menimbulkan minat untuk datang kembali. Kotler dan Keller (2009), menyatakan bahwa kepuasan pelanggan adalah perasaan senang atau kekecewaan seseorang setelah membandingkan kinerja atau hasil yang dirasakan dibandingkan dengan harapannya dan kepuasan pelanggan memiliki keterkaitan dengan kualitas pelayanan. Persaingan yang semakin ketat menyebabkan setiap perusahaan harus menempatkan orientasi pada kepuasan pelanggan sebagai tujuan utama ( Tjiptono, 2008).

Adanya banyak variabel yang dapat mempengaruhi kepuasan konsumen diantaranya adalah kualitas layanan. Zeithaml, dan Berry ( Tjiptono, 2016) membagi kualitas pelayanan ke dalam lima bentuk dimensi yang lebih sederhana yaitu tangible (bukti fisik), berkenaan dengan daya tarik fasilitas fisik, perlengkapan, dan material yang digunakan perusahaan, serta penampilan karyawan. Reliability (reliabilitas), berkaitan dengan kemampuan perusahaan untuk memberikan layanan yang akurat sejak pertama kali tanpa membuat kesalahan apapun dan menyampaikan jasanya sesuai dengan waktu yang disepakati.

Responsiveness (daya tangkap), berkenaan dengan kesediaan dan kemampuan para karyawan untuk membantu para pelanggan dan merespon permintaan mereka, serta menginformasikan kapan jasa. Assurance (jaminan) adalah yakni perilaku para karyawan mampu menumbuhkan kepercayaan terhadap perusahaan dan perusahaan bisa menciptakan rasa aman bagi para pelanggannya. Emphaty (empati) berarti bahwa perusahaan memahami masalah para pelangganya dan bertindak demi kepentingan pelanggan, serta memberikan perhatian personal kepada para pelanggan dan memiliki jam operasi yang nyaman.

Selain kualitas layanan harga yang diberikan juga berpengaruh dalan tingkat kepuasan konsumen, penetapan harga dapat mencegah masuknya pesaing, mempertahankan loyalitas pelanggan, mendukung penjualan ulang, atau menghindari campurtangan pemerintah Tjiptono (2008). Promosi merupakan salah satu faktor keberhasilan suatu program pemasaran. Betapapun berkualitasnya suatu produk, bila konsumen belum pernah mendengarnya dan tidak yakin bahwa produk itu berguna bagi mereka, maka mereka tidak akan membelinya (Tjiptono, 2008). Berdasarkan pernyataan tersebut maka dapat disimpulkan bahwa promosi merupakan variabel untuk menarik perhatian wisatawan potensial ke destinasi tertentu dan menikmati berbagai kegiatan yang dirancang dalam objek pariwisata.

Kepuasan yang diperoleh seorang konsumen, dapat mendorong ia melakukan pembelian ulang (repeat purchase), menjadi loyal terhadap produk tersebut ataupun loyal terhadap perusahaan atau tempat dia membeli jasa tersebut sehingga konsumen dapat menceritakan hal hal yang baik kepada orang lain.Mothersbaugh dan Best (dalam Yasi apriyani, 2013) pembelian kembali sebagai suatu kegiatan membeli kembali yang dilakukan oleh konsumen terhadap suatu produk dengan merek yang sama tanpa diikuti oleh perasaan yang berarti terhadap produk tersebut. Penelitian ini bertujuan untuk menganalisa apakah kualitas layanan, harga, promosi berpengaruh secara parsial terhadap kepuasan wisatawan pada wisata air Owabong, menganalisa apakah kepuasan wisatawan berpengaruh secara parsial terhadap minat kunjungan kembali pada pengunjung wisata air Owabong dan, menganalisa apakah kualitas layanan, harga, promosi berpengaruh secara simultan terhadap kepuasan wisatawan pada wisata air Owabong.

\section{Metode Penelitian}

Tipe penelitian adalah explanatory reseach, populasi yang menjadi obek dalam penelitian ini adalah pengunjung objek wisata air Owabong sedangkang sampel yang digunakan adalah pengunjung yang sudah pernah berkunjung sebelumnya. Metode pengumpulan data dalam penelitian ini yaitu data skunder yang berupa literatur dan penelitian terdahulu untuk 
mendapatkan gambaran dari masalah yang akan diteliti dan data primer yang berupa kuesioner, wawancara dan, observasi yang di lakukan pada pengunjung Owabong.

Teknis analisis data yang digunakan pada penelitian ini adalah Uji kualitas data berupa uji validitas, uji reliablitas. Uji asumsi klasik berupa uji normalitas, uji multikolenieritas, uji heteroskedastisitas. Uji hipotesis yang berupa analisis regresi linier berganda, analisis regresi linier sederhana, uji koefisien determinasi (R2), uji T (Parsial) dan, uji F (Simultan)

\section{Hasil dan Pembahasan \\ 1. Uji Kualitas Data a. Uji validitas}

Tabel 1

Hasil Pengujian Validitas Instrumen Variabel Kualitas layanan $\left(\mathrm{X}_{1}\right)$

\begin{tabular}{|c|c|c|c|}
\hline Nomor Item & Nilai r test & $\begin{array}{c}\text { Nilai r tabel } \\
(\alpha=0,05)\end{array}$ & Keterangan \\
\hline 1 & 0,679 & 0,201 & Valid \\
\hline 2 & 0,705 & 0,201 & Valid \\
\hline 3 & 0,808 & 0,201 & Valid \\
\hline 4 & 0,773 & 0,201 & Valid \\
\hline 5 & 0,852 & 0,201 & Valid \\
\hline
\end{tabular}

Sumber : Lampiran 3. Hasil Uji Kualitas Data

Tabel 2

Hasil Pengujian Validitas Instrumen Variabel Harga $\left(\mathbf{X}_{2}\right)$

\begin{tabular}{|c|c|c|c|}
\hline Nomor Item & Nilai r test & $\begin{array}{c}\text { Nilai r tabel } \\
(\alpha=0,05)\end{array}$ & Keterangan \\
\hline 1 & 0,777 & 0,201 & Valid \\
\hline 2 & 0,893 & 0,201 & Valid \\
\hline 3 & 0,850 & 0,201 & Valid \\
\hline
\end{tabular}

Sumber : Lampiran 3. Hasil Uji Kualitas Data

Tabel 3

Hasil Pengujian Validitas Instrumen Variabel Promosi $\left(\mathbf{X}_{3}\right)$

\begin{tabular}{|c|c|c|c|}
\hline Nomor Item & Nilai r test & $\begin{array}{c}\text { Nilai r tabel } \\
(\alpha=0,05)\end{array}$ & Keterangan \\
\hline 1 & 0,731 & 0,201 & Valid \\
\hline 2 & 0,759 & 0,201 & Valid \\
\hline 3 & 0,723 & 0,201 & Valid \\
\hline 4 & 0,634 & 0,201 & Valid \\
\hline
\end{tabular}

Sumber : Lampiran 3. Hasil Uji Kualitas Data.

\section{Tabel 4}

Hasil Pengujian Validitas Instrumen Variabel Kepuasan wisatawan $\left(\mathrm{Y}_{1}\right)$

\begin{tabular}{|c|c|c|c|}
\hline Nomor Item & Nilai r test & $\begin{array}{c}\text { Nilai r tabel } \\
(\alpha=0,05)\end{array}$ & Keterangan \\
\hline 1 & 0,670 & 0,201 & Valid \\
\hline 2 & 0,751 & 0,201 & Valid \\
\hline 3 & 0,764 & 0,201 & Valid \\
\hline 4 & 0,661 & 0,201 & Valid \\
\hline 5 & 0,670 & 0,201 & Valid \\
\hline
\end{tabular}

Sumber : Lampiran 3. Hasil Uji Kualitas Data 
Tabel 5

Hasil Pengujian Validitas Instrumen Variabel Minat kunjungan kembali ( $\left.\mathrm{Y}_{2}\right)$

\begin{tabular}{|c|c|c|c|}
\hline Nomor Item & Nilai r test & $\begin{array}{c}\text { Nilai r tabel } \\
(\alpha=0,05)\end{array}$ & Keterangan \\
\hline 1 & 0,785 & 0,201 & Valid \\
\hline 2 & 0,872 & 0,201 & Valid \\
\hline 3 & 0,855 & 0,201 & Valid \\
\hline
\end{tabular}

Sumber : Lampiran 3. Hasil Uji Kualitas Data

Berdasarkan data tersebut nilai $r$ test dari variabel kualitas layanan, harga, promosi, kepuasan wisatawan dan, minat kunjungan kembali lebih besar dari nilai $\mathrm{r}$ tabel pada taraf signifikansi 95 persen $(\alpha=0,05)$.

\section{b.Uji Reliabilitas}

\section{Tabel 6}

Hasil Pengujian Reliabilitas Instrumen Penelitian

\begin{tabular}{|l|c|c|c|}
\hline \multicolumn{1}{|c|}{ Variabel } & $\begin{array}{c}\text { Cronbach's } \\
\text { Alpha }\end{array}$ & $\begin{array}{c}\text { Koefisien } \\
\text { Reliabilitas }\end{array}$ & Keterangan \\
\hline Kualitas Layanan $\left(\mathrm{X}_{1}\right)$ & 0,821 & 0,600 & Reliabel \\
\hline Harga $\left(\mathrm{X}_{2}\right)$ & 0,790 & 0,600 & Reliabel \\
\hline Promosi $\left(\mathrm{X}_{3}\right)$ & 0,670 & 0,600 & Reliabel \\
\hline Kepuasan Wisatawan $\left(\mathrm{Y}_{1}\right)$ & 0,722 & 0,600 & Reliabel \\
\hline Minat Kunjungan Kembali $\left(\mathrm{Y}_{2}\right)$ & 0,775 & 0,600 & Reliabel \\
\hline
\end{tabular}

Sumber : Lampiran 3. Hasil Uji Kualitas Data

Berdasarkan data yang tersaji pada tabel 6 dapat diketahui bahwa nilai

Cronbach's alpha untuk setiap variabel yang diteliti lebih besar lebih $>0,6$. Jadi instrumen penelitian dinyatakan reliabel.

\section{Uji Asumsi Klasik}

\section{a. Uji Normalitas data}

Berdasarkan Tabel 7 dapat terlihat bahwa nilai asymp.sig. (2-tailed) $>\alpha$. Nilai asymp.sig. 0,792 > 0,05, maka nilai residual terstandardisasi model regresi yang disajikan dikatakan menyebar secara normal.

Tabel 7

Hasil Uji Normalitas Data

\begin{tabular}{llr}
\hline \multicolumn{2}{c}{ One-Sample Kolmogorov-Smirnov Test } \\
& & $\begin{array}{c}\text { Unstandardized } \\
\text { Residual }\end{array}$ \\
\hline $\mathrm{N}$ & Mean & 96 \\
Normal Parameters ${ }^{\mathrm{a}, \mathrm{b}}$ & Std. Deviation & .0000000 \\
& Absolute & .29962951 \\
Most Extreme Differences & Positive & .066 \\
& Negative & .034 \\
Kolmogorov-Smirnov Z & & .066 \\
Asymp. Sig. (2-tailed) & & .792 \\
a. Test distribution is Normal. & \\
b. Calculated from data. & \\
\hline
\end{tabular}

Sumber :Lampiran 4. Hasil Uji Asumsi Klasik 


\section{b. Uji Multikolenieritas}

Tabel 8

Hasil Uji Multikolinieritas

\begin{tabular}{|c|l|c|}
\hline No. & \multicolumn{1}{|c|}{ Variabel } & Nilai VIF \\
\hline 1. & Kualitas Layanan $\left(\mathrm{X}_{1}\right)$ & 1,311 \\
\hline 2. & Harga $\left(\mathrm{X}_{2}\right)$ & 1,245 \\
\hline 3. & Promosi $\left(\mathrm{X}_{3}\right)$ & 1,349 \\
\hline
\end{tabular}

Sumber :Lampiran 4. Hasil Uji Asumsi Klasik

Berdasarkan hasil analisis di atas diketahui bahwa nilai VIF lebih kecil kecil dari 10. Jadi tidak terdapat multikolinieritas antar variabel bebasnya, sehingga memenuhi syarat untuk melakukan analisis regresi.

\section{c. Uji Heteroskedastisitas}

Tabel 9

Hasil Uji Heteroskedastisitas

\begin{tabular}{|c|c|c|c|c|c|c|}
\hline \multirow{2}{*}{\multicolumn{2}{|c|}{ Model }} & \multicolumn{2}{|c|}{$\begin{array}{l}\text { Unstandardized } \\
\text { Coefficients }\end{array}$} & \multirow{2}{*}{$\begin{array}{c}\text { Standardized } \\
\text { Coefficients } \\
\text { Beta } \\
\end{array}$} & \multirow[t]{2}{*}{$\mathrm{t}$} & \multirow[t]{2}{*}{$\begin{array}{l}\text { Coefficie } \\
\text { nts }^{\text {a }}\end{array}$} \\
\hline & & B & Std. Error & & & \\
\hline \multirow{4}{*}{1} & (Constant) & .493 & .166 & & 2.972 & .004 \\
\hline & $\mathrm{X}_{1}$ & -.079 & .043 & -.216 & -1.852 & .067 \\
\hline & $\mathrm{X}_{2}$ & .002 & .028 & .008 & .068 & .946 \\
\hline & $\mathrm{X}_{3}$ & .007 & .044 & .018 & .149 & .882 \\
\hline
\end{tabular}

a. Dependent Variable: Absut

Sumber :Lampiran 4. Hasil Uji Asumsi Klasik

Berdasarkan Tabel 4.17 terlihat dari uji Gleyser seluruh nilai sig dari variabel kualitas layanan $\left(\mathrm{X}_{1}\right)$, harga $\left(\mathrm{X}_{2}\right)$, dan promosi $\left(\mathrm{X}_{3}\right)>0,05$ sehingga dapat disimpulkan bahwa model regresi yang disajikan tidak mengandung unsur heteroskedastisitas.

\section{d. Uji Hipotesis}

Tabel 10

Hasil Uji Regresi Linear Berganda

\begin{tabular}{|c|c|c|c|c|c|c|}
\hline \multicolumn{7}{|c|}{ Coefficients $^{\mathrm{a}}$} \\
\hline \multirow{2}{*}{\multicolumn{2}{|c|}{ Model }} & \multicolumn{2}{|c|}{ Unstandardized Coefficients } & \multirow{2}{*}{$\begin{array}{c}\text { Standardized } \\
\text { Coefficients } \\
\text { Beta } \\
\end{array}$} & \multirow[t]{2}{*}{$\mathrm{t}$} & \multirow[t]{2}{*}{ Sig. } \\
\hline & & $\mathrm{B}$ & Std. Error & & & \\
\hline \multirow{4}{*}{1} & (Constant) & 1.171 & .270 & & 4.338 & .000 \\
\hline & $\mathrm{X} 1$ & .350 & .070 & .420 & 5.026 & .000 \\
\hline & $\mathrm{X} 2$ & .091 & .046 & .162 & 1.986 & .050 \\
\hline & $\mathrm{X} 3$ & .269 & .072 & .317 & 3.740 & .000 \\
\hline
\end{tabular}

a. Dependent Variable: Y1

Sumber: Lampiran 5. Hasil Uji Hipotesis

Berdasarkan hasil analisis regresi tersebut di atas, dapat disusun persamaan regresi sebagai berikut :

$$
Y_{1}=1,171+0,350 \mathrm{X}_{1}+0,091 \mathrm{X}_{2}+0,269 \mathrm{X}_{3}+\mathrm{e}
$$

Tabel 11

Hasil Uji Regresi Sederhana

\begin{tabular}{lllll}
\hline Model & Unstandardized Coefficients & $\begin{array}{l}\text { Standardized } \\
\text { Coefficients }\end{array}$ & $\mathrm{t}$ & Sig. \\
& $\mathrm{B}$ & Std. Error & Beta & \\
\hline
\end{tabular}




\begin{tabular}{lllllll}
\hline \multirow{2}{*}{1} & (Constant) & 2.127 & .235 & & 9.047 & .000 \\
& $\mathrm{Y} 2$ & .446 & .063 & .587 & 7.031 & .000 \\
\hline
\end{tabular}

a. Dependent Variable: Y1

Sumber: Lampiran 5. Hasil Uji Hipotesis

Berdasarkan hasil analisis regresi tersebut di atas, dapat disusun persamaan regresi sebagai berikut :

$$
Y_{2}=2,127+0,446 \mathrm{Y}_{1}+\mathrm{e}
$$

Tabel 12

Hasil Uji Koefisien Determinasi (R2)

\begin{tabular}{lrrrr}
\hline Model & R & R Square & Adjusted R Square & Std. Error of the Estimate \\
\hline 1 & $.714^{\mathrm{a}}$ & .510 & .494 & .30448
\end{tabular}

a. Predictors: (Constant), X3, X2, X1

b. Dependent Variable: Y1

Berdasarkan data pada tabel 12 nilai Adjusted R Square sebesar 0,494 yang artinya kepuasan wisatawan dipengaruhi oleh kualitas layanan, harga, dan promsi sebesar 49,4\%. Sedangkan sisanya 50,6 \% kepuasan wisatawan dipengaruhi oleh variabel lain.

Tabel 13. Hasil Uji F

ANOVA $^{a}$

\begin{tabular}{|rl|r|r|r|r|r|}
\hline Model & & Sum of Squares & df & Mean Square & F & Sig. \\
\hline \multirow{2}{*}{1} & Regression & 8.881 & 3 & 2.960 & 31.932 & $.000^{\mathrm{b}}$ \\
& Residual & 8.529 & 92 & .093 & & \\
& Total & 17.410 & 95 & & & \\
\hline
\end{tabular}

a. Dependent Variable: Y1

b. Predictors: (Constant), X3, X2, X1

Sumber: Lampiran 5. Hasil Uji Hipotesis

Berdasarkan hasil analisis statistik dapat diketahui bahwa nilai $\mathrm{F}$ test sebesar 31,932. Sementara nilai $F$ tabel pada taraf kepercayaan $95 \%$ dengan derajat kebebasan, rumus mencari $\mathrm{F}$ tabel adalah df1 $=(\mathrm{k}-1)$ df2 $=(\mathrm{n}-\mathrm{k})$ dan diperoleh angka sebesar 2,47. Jadi $\mathrm{F}$ test $>\mathrm{F}$ tabel $(31,932>2,47)$.

\section{Kesimpulan dan Saran}

\section{Kesimpulan}

Berdasarkan pembahasan hasil penelitian pada bab sebelumnya dapat diambil kesimpulan sebagai berikut :

a. Kualitas layanan berpengaruh signifikan terhadap kepuasan wisatawan obejek wisata air Owabong Kabupaten Purbalingga. Hal tersebut dibuktikan dengan nilai $\mathrm{t}_{\text {test }}$ yang lebih besar daripada nilai $\mathrm{t}_{\text {tabel }}$ pada taraf kepercayaan $95 \%$. Berdasarkan hal tersebut maka hipotesis pertama diterima.

b. Harga berpengaruh signifikan terhadap kepuasan wisatawan obejek wisata air Owabong Kabupaten Purbalingga. Hal tersebut dibuktikan dengan nilai t test sama dengan nilai t tabel pada taraf kepercayaan 95\%. Berdasarkan hal tersebut maka hipotesis kedua diterima.

c. Promosi mempunyai pengaruh signifikan terhadap kepuasan wisatawan obejek wisata air Owabong Kabupaten Purbalingga. Hal tersebut dibuktikan dengan nilai t test yang lebih besar daripada nilai $t$ tabel pada taraf kepercayaan $95 \%$. Berdasarkan hal tersebut maka hipotesis ketiga diterima. 
d. Kepuasan wisatawan mempunyai pengaruh signifikan terhadap minat kunjungan kembali pada obejek wisata air Owabong Kabupaten Purbalingga. Hal tersebut dibuktikan dengan nilai t test yang lebih besar daripada nilai $t$ tabel pada taraf kepercayaan 95\%. Berdasarkan hal tersebut maka hipotesis keempat diterima.

e. Kualitas layanan, harga dan, promosi secara simultan berpengaruh signifikan terhadap kepuasan wisatawan obejek wisata air Owabong Kabupaten Purbalingga. Hal tersebut dibuktikan dengan nilai $\mathrm{F}$ test yang lebih besar daripada nilai $\mathrm{F}$ tabel pada taraf kepercayaan 95\%. Berdasarkan hal tersebut maka hipotesis kelima diterima.

\section{Saran}

a. Perusahaan untuk tetap meningkatkan kualitas layanan terutama dalam pelayanan loket pembayan tiket karena banyak terjadi keluhan karna antrian loket yang sangat panjang di hari libur, selain pelayanan loket yang perlu di perhatikan adalah penataan tempat parkir yang sering menjadi keluhan terbanyak dari responden.

b. Perusahaan untuk menetapkan harga yang sesuai dengan fasilitas dan pelayanan, walaupun pada hasil penelitian harga berpengaruh secara signifikan terhadap kepuasan wisatawan namun dengan nilai yang kecil terbukti tidak sedikit yang mengeluhkan mahalnya harga tiket masuk owabong terutama pada kolam air panas yang diharuskan membeli tiket lagi untuk masuk ke wanahana tersebut.

c. Perusahaan disarankan untuk meningkatkan promosi terutama dalam promosi penjualan karena tidak semua pengunjung merasakan promosi penjualan yang di berikan oleh pihak pengelola perusahaan, tidak meratanya promosi yang di berikan juga di keluhkan oleh wisatawan.

d. Perusahaan untuk menjadikan kepuasan wisatawan sebagai tujuan utama dalam memberikan pelayanan karna terbukti dari hasil analisis yang menunjukan bahwa kepuasan wisatawan sangat mempengaruhi minat kunjungan kembali wisatawan ke Owabong.

e. Berdasarkan data yang telah diteliti, kepuasan wisatawan dipengaruhi oleh kualitas layanan, harga, dan promsi sebesar 49,4\%. Sedangkan sisanya 50,6\% kepuasan wisatawan dipengaruhi oleh variabel variabel laian. Diharapkan hasil penelitian ini dapat dipakai sebagai acuan bagi peneliti selanjutnya untuk mengembangkan penelitian ini dengan mempertimbangkan variabel-variabel lain yang merupakan variabel lain yang belum tercantum. Variabel yang bisa dikembangkan adalah Fasilitas wisata, kemampuan daya beli, kualitas produk. Beberapa hal tersebut dapat dijadikan variabel tambahan untuk penelitian selanjutnya sehingga hasil penelitian pengaruh kepuasan wisatawan akan semakin baik.

\section{Daftar Pustaka}

Apriyani, Yesi. 2013. Pengaruh Brand Image, Harga Dan Kualitas Pelayanan Terhadap Keputusan Pembelian Ulang Pizza Hut Di Kota Padang. Jurnal Ekonomi. Universitas Negeri Padang. Vol. 2 No. 1.

Abror, Tabrani, Gesit dan Elfani, Riyeni Dwi. 2013. Pengaruh Kualitas Layanan Kawasan Wisata Pantai Carocok Painan Terhadap Kepuasan Wisatawan. Jurnal Ekonomi. Ekonomi Universitas Negeri Padang. Vol. 2 No. 2.

Augusty, Ferdinand. 2006. Metode Penelitian Manajemen: Pedoman Penelitian untuk skripsi, Tesis dan Disertai Ilmu Manajemen. Semarang: Universitas Diponegoro.

Bhuwana, Made Bagus Rangga dan Sudiksa, Ida Bgs. 2013. Pengaruh Kualitas Layanan Dan Kepuasan Pelanggan Terhadap Niat Pemakaian Ulang Jasa Service Pada Bengkel Toyota Auto 2000 Denpasar.Jurnal Ekonomi. Universitas Udayana Bali. Vol. 2 No.4. 
Ghozali, I. 2011. Aplikasi Analisis Multivariate dengan Program IBM SPSS19. Badan Penerbit Universitas Diponegoro. Semarang.

Gulla, Rendy, Oroh, Sem George dan Roring, Ferdy. 2015. Analisis Harga, Promosi, Dan Kualitas Pelayanan Terhadap Kepuasan Konsumen Pada Hotel Manado Grace Inn. Jurnal Ekonomi. Universitas Sam Ratulangi Manado. Vol. 3 No. 1, hal 1313 - 1322.

Haryanto, Resty Avita. 2013. Strategi Promosi, Kualitas Produk, Kualitas Layanan Terhadap Kepuasan Pelanggan Pada Restoran Mcdonald's Manado. Jurnal Ekonomi Universitas Sam Ratulagi Manado, Vol. 1 No. 4, hal 1465 - 1473.

Hasan, Ali. 2015. Taurism Markting. Penerbit CAPS (Center for Academic Publishhing Service). Yogyakarta

Jung Choi, Eun and Kim, Soo-Hyun. 2013. The Study of the Impact of Perceived Quality and Value of Social Enterprises on Customer Satisfaction and Re-Purchase Intention.International Journal. Sangmyung University.

Kotler, Philip, dan Kerller, K. L 2009. Manajemen Pemasaran. Edisi 13. Jilid 1. Jakarta : Erlangga.

Erlangga.

,2009. Manajemen Pemasaran. Edisi 13. Jilid 2. Jakarta :

Schiffman, L., dan Kanuk, L. L. (2007). Perilaku Konsumen. Edisi Ketujuh. Jakarta : PT. Indeks Gramedia.

Sugiyono. 2014. Cara Muda Menyusun Skripsi, Tesis Dan Disertasi. Bandung : Alfabeta.

Tjiptono, Fandy. 2006. Manajemen Jasa. Edisi Pertama. Yogyakarta : C.V Andi Offset.

2007. Pemasaran Jasa. Edisi Pertama, Malang, Penerbit : Bayumedia Publishing.

2008. Strategi Pemasaran. Edisi Ketiga. Yogyakarta : C.V Andi Offset.

, 2016. Service, Quality dan Satisfaction. Edisi 4. Yogyakarta : C.V Andi Offset.

Kementrian Pariwisata Republik Indonesia [Internet]. Tersedia dalam : http://www.kemenpar.go.id/asp/detil.asp?c=112\&id=1358 [Accessed 28 November 2016].

Tabloid Pamor [Internet]. Purwokerto. Tersedia dalam : http://www.tabloidpamor.com/berita487-157-juta-wisatawan-ke-purbalingga.htm[Accessed 10 Oktober 2016]. 